\title{
1/29 Robertsonian translocation in Blonde d'Aquitaine bulls: frequency and effects on semen characteristics
}

\author{
F Gary, D Concordet, HM Berland, X Berthelot, R Darré \\ Ecole Nationale Vétérinaire de Toulouse, \\ Département des Productions Animales, Laboratoire INRA de Cytogénétique, \\ 23, chemin des Capelles, F-31076 Toulouse Cedex, France
}

(Proceedings of the 9th European Colloquium on Cytogenetics of Domestic Animals; Toulouse-Auzeville, 10-13 July 1990)

bull / Robertsonian translocation / 1/29 / frequency / semen

\section{INTRODUCTION}

In cattle, Robertsonian translocations are known to affect fertility of carrier breeders. In the Blonde d'Aquitaine breed, an earlier study (Frebling et al, 1987) showed that $14.2 \%$ of the females from selection herds were translocated. These results justified further investigations to determine the frequency of the $1 / 29$ centric fusion in Blonde d'Aquitaine bulls and its effects upon semen characteristics.

\section{MATERIALS AND METHOD}

Study of the frequency of the 1/29 translocation in bulls used for natural breeding In 1986-87, cytogenetic analyses were carried out on 157 Blonde d'Aquitaine bulls used for natural breeding, representing $80 \%$ of the natural breeding bulls in selection herds. Karyotypic analyses were performed using conventional staining methods (de Grouchy et al, 1964).

Semen characteristics from translocated bulls

Semen samples from 23 bulls, 15-18 months old, were analyzed at the Laboratoire National de Contrôle des Reproducteurs, Maisons-Alfort, to evaluate their sexual functions. 5 bulls carried the $1 / 29$ translocation and 18 were normal. The parameters investigated were: volume, wave motility (scored from 1 to 5 ), concentration of spermatozoa, abnormal spermatozoa (frequency and distribution of the abnormalities) in fresh ejaculates; percentage of normal and dead spermatozoa after deep-freezing.

For the statistical analysis, we considered that the effects of the $1 / 29$ centric fusion were identical for all bulls. The lack of a bull effect was controlled by analysis 
of variance on the seminal characteristics in groups of translocated or normal bulls. Mean values and standard deviations of seminal characteristics were calculated and Student's $t$ test was performed. The overall significant level was 0.05 .

\section{RESULTS}

Frequency of the 1/29 translocation in bulls used for natural breeding

Among the 157 natural breeding bulls karyotyped, 34 (22\%) were carriers of the $1 / 29$ translocation and one was a homozygous carrier. $47 \%$ of these translocated bulls and $24 \%$ of the normal bulls had a translocated AI bull as their father or one of their grandfathers. $41 \%$ of the translocated bulls and $24 \%$ of the normal bulls were descended from a father or a grandfather used for natural breeding.

\section{Semen characteristics of translocated bulls}

The mean values for the seminal characteristics of translocated and normal bulls were not different (table I), except for a lower concentration of spermatozoa in translocated bulls' ejaculates $(P<0.05)$. There was no significant bull effect on sperm concentration in either carrier or non-carrier groups. The distribution of spermatozoan abnormalities, observed by light microscopy (abnormalities of the head, neck, middle piece and tail, cytoplasmic drop), did not differ between the two groups.

Table I. Mean values \pm standard deviation $(S D)$ of semen characteristics according to karyotype.

\begin{tabular}{|c|c|c|c|}
\hline $\begin{array}{l}\text { Semen } \\
\text { characteristics }\end{array}$ & $\begin{array}{c}19 \text { ejaculates from } \\
5 \text { translocated bulls } \\
(m \pm S D)\end{array}$ & $\begin{array}{c}57 \text { ejaculates from } \\
18 \text { normal bulls } \\
(m \pm S D)\end{array}$ & $\begin{array}{c}\text { Significance } \\
\text { of the } \\
\text { difference }\end{array}$ \\
\hline \multicolumn{4}{|l|}{ Fresh semen } \\
\hline volume $(\mathrm{ml})$ & $4.0 \pm 1.2$ & $3.6 \pm 1.1$ & NS \\
\hline wave motility & $3.8 \pm 0.3$ & $3.9 \pm 0.3$ & NS \\
\hline concentration $(10000 / \mathrm{ml})$ & $153.2 \pm 51.5$ & $184.3 \pm 48.9$ & $P<0.05$ \\
\hline \% abnormal spermatozoa & $18.2 \pm 8.5$ & $21.8 \pm 8.1$ & NS \\
\hline$\%$ acrosomal abnormalities & $0.4 \pm 0.6$ & $1.2 \pm 2.7$ & NS \\
\hline$\%$ head abnormalities & $4.6 \pm 3.3$ & $6.8 \pm 4.9$ & NS \\
\hline$\%$ neck abnormalities & $5.2 \pm 3.4$ & $7.8 \pm 4.5$ & NS \\
\hline \multicolumn{4}{|l|}{$\%$ middle piece and tail } \\
\hline$\%$ cytoplasmic drops & $2.9 \pm 4.8$ & $1.6 \pm 1.5$ & NS \\
\hline \multicolumn{4}{|l|}{ After freezing } \\
\hline$\%$ dead spermatozoa & $32.6 \pm 3.5$ & $30.8 \pm 0.36$ & NS \\
\hline \% normal spermatozoa & $34.7 \pm 10.2$ & $37.9 \pm 9.8$ & NS \\
\hline
\end{tabular}




\section{DISCUSSION}

The frequency of the $1 / 29$ translocation was higher in natural breeding bulls than in 2000 heifers from selection herds (14.2\%) (Frebling et al, 1987). There were more AI translocated bulls and natural mating sires with unknown chromosomal status among ancestors of translocated bulls than of normal bulls. To improve eradication efficiency, we recommend that farmers buy only breeders that have been tested for the $1 / 29$ translocation.

Our results, obtained from a limited number of young bulls not preselected for their sexual function, confirmed the absence of a deleterious effect of the $1 / 29$ translocation upon semen quality and freezability in heterozygous bulls (Dyrendhal and Gustavsson, 1979; Bétancourt, 1983; Moustafa et al, 1983). In concordance with our results, some researchers observed a drop in sperm concentration in translocated bulls (Queinnec et al, 1974; Dyrendhal and Gustavsson, 1979), although this was not confirmed by others (Bétancourt, 1983; Moustafa et al, 1983). Only Morelli et al (1985) detected more spermatozoan abnormalities in translocated bulls.

Since semen quality and freezability were not affected by the translocation, the selection based on seminal characteristics does not enable us to eliminate carrier bulls. Such results justify karyotypic analyses in bulls selected for artificial insemination or natural breeding. Further investigations are needed in the Blonde d'Aquitaine breed to confirm the effects of $1 / 29$ centric fusion upon male fertility observed in Swedish cattle (Dyrendhal and Gustavsson, 1979).

\section{REFERENCES}

Bétancourt A (1983) Caracteristicas seminales y fertilidad de toros Santa Gertrudis con translocaciòn 1/29. Rev Salud Anim 5, 149-158

de Grouchy J, Roubin M, Passage E (1964) Microtechniques pour l'étude des chromosomes humains à partir d'une culture de leucocytes sanguins. Ann Génét 7, 45-46

Dyrendhal I, Gustavsson I (1979) Sexual functions, semen characteristics and fertility of bulls carrying the $1 / 29$ chromosome translocation. Hereditas $90,281-289$

Frebling J, Foulley JL, Berland HM, Popescu CP, Cribiu EP, Darré R (1987) Résultats de l'enquête sur la fréquence de la translocation 1/29 en race bovine Blonde d'Aquitaine. Bull Tech CRZV INRA 67, 49-58

Morelli RH, Pineirho LEL, Malheiros EB (1985) Avaliaçao fisico-morfologica dos espermatozoides de bovinos normais e de portadores da translocaçao robertsoniana 1/29. Ars Vet $1,103-110$

Moustafa AR, Ibrahim H, Rahman HA, Kovacs A (1983) Quality, freezability and fertility of the semen of pre-selected AI bulls carrying various chromosome aberrations. Anim Reprod Sci 6, 167-175

Queinnec G, Darré R., Berland HM, Raynaud JC (1974) Etude de la translocation 1/29 dans la population bovine du Sud-Ouest de la France: conséquences zootechniques. In: 1st World Congress on Genetics Applied to Livestock Production, Madrid, 7-11 Oct 1974. Garsi, Madrid, vol 3, 131-151 